\title{
Economic Factor and Value Relevance of Accounting Information in Bangladesh
}

\section{Md. Hasan Uddin}

Department of Finance and Banking, Faculty of Business Administration and Management, Patuakhali Science and Technology University, Dumki, Patuakhali-8602, Bangladesh, E-mail: hasan14860@gmail.com

\begin{abstract}
The purpose of this study is to examine the impact of economic factors, namely, foreign ownership and trading volume on the value relevance of accounting information. Value-relevance is measured by the adjusted $R 2$ derived from a regression of stock price on EPS, BVPS, and CFPS using the price model. The study sample included 71 manufacturing companies listed with Dhaka Stock Exchange (DSE) in Bangladesh within the period 2000-2017. The results of this study showed that earnings (EPS), book value (BVPS), and cash flow (CFPS) are value relevant to the share price. This paper found that the value relevance of EPS and BVPS is greater for companies having foreign ownership and the value relevance of BVPS and CFPS is greater for companies' larger trading volume. The findings suggest that market participants might be able to extract the firm value via these economic factors. This paper presents the ability of valuation theory/model to interact with other theories by including the impact of economic factors on the accounting information value relevance. This study may introduce proof that can serve the educational institutions in their courses and provide a guideline to investors, managers and financial analysts to better summarize the firm value. This research likewise makes windows for future studies toward this path for different sectors.

Key words

Value Relevance, Accounting Information, Economic Factors, Manufacturing Sector and Bangladesh

Received: 15 April $2020 \quad$ C The Authors 2020

Revised: 14 May 2020 Published by Human Resource Management Academic Research Society (www.hrmars.com)

Accepted: 21 May 2020 This article is published under the Creative Commons Attribution (CC BY 4.0) license. Anyone may Published Online: 09 Jun 2020 reproduce, distribute, translate and create derivative works of this article (for both commercial and non-commercial purposes), subject to full attribution to the original publication and authors. The full terms of this license may be seen at: http://creativecommons.org/licences/by/4.0/legalcode
\end{abstract}

\section{Introduction}

The value relevance of accounting information has been influenced by many institutional factors. Ongoing value relevance studies across the country have identified and implemented these factors (Ali \& Hwang, 2000; Hung, 2001; Ball et al., 2003; Anandarajan and Hasan, 2010). For the purposes of this study, the influence of economic factors namely foreign ownership and trading volume is significant and important factor affecting the value relevance of earnings (EPS), book value (BVPS), and cash flows (CFPS). The researcher attempts to look at to what degree these factors can influence the value relevance of accounting information for manufacturing companies listed in Dhaka Stock Exchange (DSE).

Investments depend on the transferring of management and capital across national boundaries, foreign investors have been considered as proprietors and not merely lenders (Staley, 1935). Investment management and capital depend on the transfer of national boundaries, treating foreign investors as owners and not just creditors (Staley, 1935). The financial efficiency of companies is shifted according to the foreign ownership (Boubakri et al., 2005). In short, as the firm's financial capacity grows, so does the amount of foreign ownership of the firm (Anadarjan and Hassan, 2010). Several studies have found that a 
high proportion of foreign ownership is positively associated with firm performance (Denizar, 2000; Litan et al., 2001; Anandarajan \& Hassan, 2010). Like other countries, Bangladesh is seeking to increase foreign investment in the local economy, which needs to use relevant information from financial statements that reflect market performance. Since the current study examines the influence of this factor on the value relevance of earnings (EPS), book value (BVPS), and cash flows (CFPS), it is clear that foreign ownership theory is relevant for adoption in this study.

Previous research demonstrates that there is still no consensus in the academic literature on the influence of trading volume on the value relevance of accounting information, when trading is a valuable source of information about the value of assets (Kim \& Verrecchia, 2001). Since trading volume has negative influence (Dontoh et al., 2004), significant influence (Shamki, 2013), insignificant influence (Liu \& Liu, 2007) on the value relevance of accounting information, positive relationship with price change (Clark, 1973; Epps \& Epps, 1976; Tauchen \& Pitts, 1983) and noisy relationship with price change (Pfleiderer, 1984), this study does not expect the influence of trading volume on the value relevance of the accounting information in Bangladesh.

The paper extends these studies by examining the influence of foreign ownership and trading volume on the value relevance of earnings (EPS), book value (BVPS), and cash flows (CFPS) simultaneously. The paper's question is: Can foreign ownership and trading volume influence the value relevance of earnings (EPS), book value (BVPS), and cash flows (CFPS) in Bangladesh? Accordingly, the paper objects to examine whether foreign ownership and trading volume can influence the value relevance of earnings (EPS), book value (BVPS), and cash flows (CFPS).

\section{Literature review}

As the more profound and important factors that affected the value relevance of accounting information are the economic factors. For the purpose of this paper, the influence of the economic factors is traced by the influence of foreign ownership and trading volume on the value relevance of earnings (EPS), book value (BVPS), and cash flows (CFPS).

\subsection{Value Relevance and Foreign Ownership}

According to Anandarajan \& Hasan, (2010), excessive presence of foreign ownership leads to increased competitiveness, which improves the efficiency and performance of the local firm. This is on the grounds that foreign investment introduces sophisticated information technology (Okuda \& Rungsomboon, 2004). This leads to lower operating costs and increased profitability, thus doubling the efforts of local firms to maintain competitiveness (Claessens et al., 2001; Berger \& Hannan, 1998; Anandarajan \& Hasan, 2010). Many studies have been conducted focusing on the determinants of foreign investment in local firms (Sethi et al., 2003). Significant associations of these investments have been found with technological intensity (Lall, 1980), firm size (Li \& Guisinger, 1992), capital intensity (Pugel, 1981), product differentiation (Caves, 1971) and both large scale financial and firm methodology factors (Sethi et al., 2003).

Likewise, foreign ownership association has positive influence on the domestic industry in improving efficiency and competitiveness. Anandarajan and Hasan, (2010) found that foreign ownership participation has a strong positive impact on the value relevance of the accounting information. Bae \& Jeong (2007) and Shamki (2013) examined the effect of foreign ownership on the value of relevance of accounting information. They found that foreign ownership positively influences the value relevance of earnings in Korean companies and Jordanian companies respectively. Since the extent of foreign ownership has a strong positive influence on the value relevance of earnings (Bae \& Jeong, 2007; Anandarajan \& Hasan, 2010), it is expected that extending foreign ownership in Bangladesh will also have positive influence on the value relevance of earnings (EPS), book value (BVPS), and cash flows (CFPS). One of the independent variables of the current study is foreign ownership, which measures whether a firm has foreign ownership at the end of the financial year (Anandarajan \& Hasan, 2010).

\subsection{Value Relevance and Trade Volume}

Earlier literary works found that trading volume does not play as a source of information about firm value (Admati \& Pfleiderer, 1988; Varian, 1989; Kim \& Verrecchia, 1991; Harris \& Raviv, 1993; Kandel \& 
Pearson, 1995). If the disclosure of financial information is postponed in the future, trading volume will be used to draw conclusions about better information about firm value (Verrecchia, 2001; Kim \& Verrecchia, 2001). Many studies have used the relationship between trading volume and earnings announcement or share price (Karpoff, 1986; Kim \& Verrecchia, 1991; Bamber \& Cheon, 1995). These studies have eliminated the positive relationship between stock prices and trading volume in the announcement of earnings. Beaver (1968) found that earnings announcements resulted in abnormal price changes and abnormally high trading volumes. Variation in earnings induces higher trade volume than pre-disclosure price fluctuations (Bamber \& Cheon, 1995). These findings suggest that trading volume is more strongly associated with investors' uncertainty (Callahan et al., 1997).

Karpoff (1986) examined the relationship between trading volume and share price and found that the share price-trading volume relation is important because it provides (1) insight into financial markets structure, (2) studies the use of a combination event and the price and volume data for their decisions, (3) it is important to discuss the dynamic allocation of pricing forecasts and (4) has important implications for future market research in which price differences affect the trading volume in future contracts.

Shamki (2013) examined the impact of economic factors such as foreign ownership and trading volume on the value relevance of earnings, book value and cash flows relative to the share price for Jordanian services and industrial companies within the period 2004-2009. The study found that for firms with large trading volumes, earnings and book value were higher. Dontoh et al. (2004) examined the prediction that the value of accounting information decreases as trading volume increases and their results support the prediction. They found that the value relevance of earnings and book values is negatively correlated with the trading volume, In the Chinese stock market, Liu \&Liu (2007) examined the impact of trading volume on the value relevance of earnings and book value and have found it statistically insignificant, although Chen et al. (2001) have found that with high trading volume, earnings and book value were more value relevant.

Since there is no clear understanding of the effect of trading volume on the value of accounting information in previous literature, this paper extends the studies of Chen et al. (2001), Dontoh et al. (2004), and Liu \& Liu (2007) by adding cash flows from operation (CFPS) as a new variable with earnings (EPS) and book value (BVPS) to examine the influence of trading volume on the value relevance of these accounting variables in Bangladesh. Trading volume as one of the independent variables studied is now measured by the number of shares sold by the company at the end of the financial year (Cready 1988; Cready \& Mynatt 1991; Bhattacharya, 2001).

\subsection{Company's Size and Leverage}

As referred in prior research, many variables have been found to be controlled when examining the value relevance of the accounting information. The company's size and leverage are the paper's control variables. Following previous literature (Anandarajan \& Hasan, 2010; Shamki \& Alulis, 2016; Jabar, 2012; Shamki, 2012 and 2013) the present study controlled firm size while looking at the value relevance of the accounting information. This is authentic, in light of the fact that large companies have large accounting variables then huge profit, book worth, and incomes. As indicated by the financial theory, financial leverage (using the debt capital) will extend the financial risk. While a positive association has been found between the financial leverage and the equity risk (Hamada, 1972; Galai \& Masulis, 1976; Karma \& Sander, 2006), a negative association between leverage and a firm's profitability has been found (Rajan \& Zingales, 1995; De Jong et al., 2008; Verwijmeren and Derwall, 2010). Leverage is similarly associated with the present study as a control variable since firms' risk level is expressed to expect a coordinating activity according to the components that impact the value relevance of accounting information (Joos \& Lang, 1994).

\section{Methodology of research}

\subsection{Hypotheses Development and Model Specification}

Since this study intends to inspect whether the earnings, book value and cash flows relevance is affectd by economic factors (foreign ownership and trading volume), the connections among study variables are hypothesized as per the stock price as follows:

$H_{a 1}$ : Foreign ownership has a significant impact on the value relevance of accounting information. 
$H_{a 2}$ : Trading volume has a significant impact on the value relevance of accounting information.

As per the valuation theory, two valuation models are regularly utilized in in value relevance studies namely the price and return models. Price Model estimates the capacity of accounting information to clarify market values of equity. The Ohlson (1995) Price Valuation Model has been used in the current examination to decide the value relevance of accounting information. This model expresses market price per share (P) as a component of both earnings per share (EPS) and book value per share (BVPS). An exact adjustment of Ohlson's theoretical model has been used widely in the value relevance literature (Barth, 2000; Barth et al., 2001; Ota, 2003, 2010; Suwardi, 2009; Hadi, 2005; Burgstahler \& Dichev, 1997; Collins et al., 1997; Barth et al., 1998; Collins et al., 1999; Easton, 1999; and Easton \& Sommers, 2000).

This paper utilizes the valuation framework developed by Ohlson (1995) to inspect the value relevance of earnings per share and book value of equity per share in addition to cash flow per share following Dechow (1994); Ortega (2006); Anandarajan \& Hasan, (2010); Khanagha et al. (2011) and Shamki \& Abdul Rahman, (2012). In like manner, standard multiple regressions are used to check the connections between dependent variable and independent variables in the wake of controlling firms' size and leverage, the price model is adopted:

$$
P_{i t}=\beta_{0}+\beta_{1} E P S_{i t}+\beta_{2} \text { BVPS }_{i t}+\beta_{3} \text { CFPS }_{i t}+\beta_{4} \text { SIZE }+\beta_{5} \text { LEVRG }+e_{i t}
$$

Where, for firm i at the end of a year $t$;

$P=$ Average annual share price refers to annual rates of share price of a company for the financial year (Grabowski \& Mueller, 1975; Oyerinde, 2009); EPS = EPS refer to earnings per share of a company at end of the financial year (Bae \& Jeong, 2007; Anandarajan \& Hasan, 2010; Al Arussi et al., 2009 and Shamki \& Alulis, 2016; Shamki \& Abdul Rahman, 2012);

BVPS = BVPS refers to book value of equity per share of a company at end of the financial year (Bae and Jeong, 2007; Shamki \&Abdul Rahman, 2012; Anandarajan \& Hasan, 2010; Al Arussi et al., 2009 and Shamki \& Alulis, 2016);

CFPS $=$ CFPS refer to cash flows from operating activities per share of a company at end of the financial year (Shamki, 2013; Anandarajan \& Hasan, 2010);

SIZE = SIZE refers to the natural logarithm of total assets of a company at end of the financial year (Hassan, 2004; and Anandarajan \& Hasan, 2010) and

LEVRG = Leverage refers to the ratio of debt to total assets of a company at end of the financial year (Anandarajan \& Hasan, 2010; Choi et al., 2011).

In this study, EPS, BVPS, and CFPS are interacted with the selected economic factors (foreign ownership and trading volume), to capture the impact of these factors on the value relevance of accounting information. As per Hartmann \& Moers (1999), this model is thought to be the reasonable one by including the interaction term of a particular variable on the connection between the dependent and independent variables. To test the impact of the economic factors (foreign ownership and trading volume) on the value relevance of accounting variables, interaction term (accounting variable ${ }^{*}$ economic factors) is included in Price Model.

Therefore, the general price model is:

$$
P_{\text {it }}=\alpha_{0}+\beta_{1} \text { EF }+\beta_{2} \text { EPS }+\beta_{3} \text { EPS EF }+\beta_{4} \text { BVPS }+\beta_{5} \text { BVPS EF }+\beta_{6} \text { CFPS }+\beta_{7} \text { CFPS EF }+\beta_{8} \text { SIZE }+\beta_{9}
$$
LEVRG $+\mathrm{e}_{i t}$

Where, $\mathrm{EF}=$ economic factors (foreign ownership and trading volume); $\mathrm{EF}$ FORN, TRDV = economic factors as a dummy variable with value 1 for; FORN = dummy variable with value 1 for companies having foreign ownership at the end of financial year; TRDV = dummy variable with value 1 for companies with trading volume greater than median trading volume, 0 otherwise; and other variables are defined before.

To test the hypothesis, the following models are used in this paper:

$$
P_{\text {it }}=\beta_{0}+\beta_{1} \text { FORN }+\beta_{2} \text { EPS }+\beta_{3} \text { EPS* FORN }+\beta_{4} \text { BVPS }+\beta_{5} \text { BVPS* FORN }+\beta_{6} \text { CFPS }+\beta_{7} \text { CFPS* FORN }+
$$
$\beta_{8}$ SIZE $+\beta_{9}$ LEVRG $+e_{\text {it }}$

$$
P_{i t}=\beta_{0}+\beta_{1} \text { TRDV }+\beta_{2} \text { EPS }+\beta_{3} \text { EPS } * \text { TRDV }+\beta_{4} \text { BVPS }+\beta_{5} \text { BVPS* TRDV }+\beta_{6} \text { CFPS }+\beta_{7} \text { CFPS* TRDV }+\beta_{8}
$$
SIZE $+\beta_{9}$ LEVRG $+e_{\text {it }}$

Coefficients with number 1 represent the value relevance of company characteristics in their rights. Coefficients numbered 2, 4 and 6 represent earnings, book value and cash flows relevance respectively 
without the impact of economic factors. Coefficients $2+3,4+5$ and $6+7$ summarize the response of stock price to earnings, book value and cash flows respectively with the impact of economic factors. It is assume that $\mathrm{H}_{01}$ and $\mathrm{H}_{02}$ as $\mathrm{H}_{0}: \beta_{3}=0, \beta_{5}=0$ or $\beta_{7}=0$.

\subsection{Sample and Data Collection}

This study has concentrated on listed manufacturing companies of the Dhaka Stock Exchange. The study has chosen those manufacturing companies listed with DES in the year 2000 or before. This is on the grounds that this study has used information for 18 years from 2000 to 2017. As indicated by these criteria 71 manufacturing companies have chosen for the study.

\subsection{Technique of Data Analysis}

The multiple regression models are broadly utilized in earlier research to analyze the value relevance of the accounting information (Harris et al., 1994; Collins et al., 1997; Pirie \& Smith, 2008 and among others). This paper has likewise used pooled regression following the methodology of Pirie \& Smith (2008) with a basic empirical model that connect share price. As per Cavana et al. (2001) as study models incorporate numerous independent variables, balanced $R^{2}$ which is one of multiple regression outputs helps with evaluating the connection quality among the study variables. To assess study models it needs to consider $F$ statistics significance. Following previous studies on the value relevance (Shamki, 2012, 2013; Shamki \& Rahman, 2013), this paper relies upon the measurable estimations of the related coefficients of the pooled test in assessing its hypotheses.

\section{Research results and discussions}

This part contains the study results which mean to look at whether listed manufacturing company's company characteristics (stockholders number and company's age) influence its accounting information relevance and display the study results according to the study hypothesis. To confirm the hypothesis genuineness, multiple linear regression analysis tests were used to identify the relationship between economic factors (foreign ownership and trading volume) and value relevance of accounting information.

\subsection{Descriptive Statistics}

The descriptive statistics provide data's distribution profile to ensure that the sample is distributed normally. The entirety of the skewness and kurtosis values except share price are within \pm 2 which ensures the normal distribution of the sample. To wipe out the non-normal distribution of share price, transformation process has to be done by natural logarithm transformation method, following Pallant \& Manual (2007). Using SPSS, descriptive statistics for stock price measures, accounting information, and control variables are determined in Table-1. The descriptive statistics table shows that the annual share price has a mean and standard deviation of Tk. 3.83 and Tk. 1.4074 respectively. Among the accounting variables, book value per share shows the highest standard deviation while the least is appeared by income per share. The table indicates that $22 \%$ of foreign ownership and $50 \%$ of trade volume in the sample are larger than their median numbers in study companies' sample.

Table 1. Descriptive Statistics of the Panel Data Series

\begin{tabular}{|l|c|c|c|c|c|c|c|c|}
\hline & PRICE & EPS & BVPS & CFPS & SIZE & LEVRG & FORN & TRDV \\
\hline $\mathrm{N}$ & 1278 & 1278 & 1278 & 1278 & 1278 & 1278 & 1278 & 1278 \\
\hline Mean & 3.83 & 6.315 & 43.88 & 9.13 & 20.45 & 0.78 & 0.22 & 0.50 \\
\hline Std. Deviation & 1.41 & 14.25 & 60.46 & 27.42 & 1.501 & 2.27 & 0.41 & 0.50 \\
\hline Skewness & 0.32 & 0.00 & 0.00 & 0.00 & 0.082 & 22.65 & 1.35 & -0.006 \\
\hline Kurtosis & -0.48 & -0.08 & -0.08 & -0.08 & 0.43 & 611.87 & 2.81 & 1.00 \\
\hline Minimum & 0.33 & -38.9 & -148.2 & -77.8 & 14.77 & 0.00 & 0.0 & 0.0 \\
\hline Maximum & 8.15 & 51.59 & 235.96 & 96.22 & 25.71 & 67.41 & 1.0 & 1.0 \\
\hline
\end{tabular}

Source: Annual Reports (2000-2017)

Notes: i) Date are derived from output on SPSS 23.0; ii) Data have been compiled by researcher. 


\subsection{Value Relevance of Accounting Information}

Table- 2 shows that the overall $R$-square is 0.536678 . This demonstrates the model has accounted for a $53.67 \%$ variation in share price by the independent variables.' $F$ ' value is significant at $1 \%$ level. This implies that independent variables (EPS, BVPS, CFPS, SIZE, and LERVG) have a significant impact on the market price of the security.

For the combined EPS, BVPS and CFPS in the price model all variables individually are value relevant relating to the share price. This is demonstrated by the significant positive coefficients on these variables $\left(\beta_{1}, \beta_{2}\right.$, and $\left.\beta_{3}\right)$, demonstrating an increase in the value relevance of these accounting variables. This result is consistent with the previous studies (Lev, 1989; Ou et al., 1989; Barth, 1991; Easton \& Harris, 1991; Penman, 1991; Easton et al., 1992; Dechow, 1994; Ohlson, 1995; Feltham \& Ohlson, 1995; Barth \& Kallapur, 1996; Collins et al., 1997; Cheng et al., 1997; Ely \& Waymire, 1999; Easton, 1999; Alsalman, 2003; Bao, 2004; Anandarajan \& Hasan, 2006; Verwijmeren \& Derwall, 2007; Vishnani \& Shah, 2008).

Table 2. Accounting Information Value Relevance

\begin{tabular}{|c|c|c|c|c|}
\hline \multicolumn{5}{|c|}{$P_{i t}=\beta_{0}+\beta_{1} E S_{i t}+\beta_{2} B V P S_{i t}+\beta_{3} C_{C F P S}+\beta_{4}$ SIZE $+\beta_{5}$ LEVRG $+e_{i t}$} \\
\hline Variable & Coefficient & Std. Error & t-Statistic & Prob. \\
\hline C & 1.369737 & 0.422629 & 3.240992 & 0.0012 \\
\hline EPS & $0.044187^{*}$ & 0.002400 & 18.41385 & 0.000 \\
\hline BVPS & $0.003897 *$ & 0.000641 & 6.076999 & 0.000 \\
\hline CFPS & $0.011420 *$ & 0.001121 & 10.19173 & 0.000 \\
\hline SIZE & $0.092320^{*}$ & 0.021195 & 4.355802 & 0.000 \\
\hline LEVRG & 0.017029 & 0.012932 & 1.316812 & 0.188 \\
\hline$R$-squared & \multicolumn{4}{|l|}{0.536678} \\
\hline Adjusted $R$-squared & \multicolumn{4}{|l|}{0.534850} \\
\hline F-statistic & \multicolumn{4}{|l|}{ 293.5199* } \\
\hline Prob(F-statistic) & \multicolumn{4}{|l|}{0.000} \\
\hline
\end{tabular}

Source: Annual Reports (2000-2017)

Notes: i) Date are derived from output on E-Views 10.0

ii) $* * * ; * *$ Significant at $1 \% ; 5 \%$ and $10 \%$ levels respectively.

iii) Data have been compiled by researcher.

\subsection{Value Relevance and Foreign Ownership}

Table-3 shows that the overall $R$-square is 0.552 . The value implies that about $55.2 \%$ of the variation in share price is explained by the independent variables. From the perusal of results in Table 3 , it has been found that ' $F$ ' value is significant at $1 \%$ level. This implies that independent variables have a significant impact on the market price of the security. The result shows that including the interaction of shareholder numbers in the regression model adjusted $R^{2}(0.549)$ is the same as that of adjusted $R^{2}(0.534)$ in Table- 2 . This increase in adjusted $R^{2}$ values is largely attributable to an increase in the effect of foreign ownership.

The coefficients on EPS, BVPS, and CFPS $\left(\beta_{2}=0.040, \beta_{4}=0.003, \beta_{6}=0.013\right.$ respectively) are significant at 0.01 level and demonstrate the value relevance of EPS, BVPS, and CFPS in the absence of the impact of the foreign ownership. However, the results show that the coefficient on foreign ownership $\left(\beta_{1}=-0.207\right)$ is significant at 0.05 level. This demonstrates that foreign ownership is value relevant in its right. Foreign ownership shows significant influence on the value relevance of earnings and book value as demonstrated by the significant coefficients on EPS interaction variable $\left(\beta_{3}=0.022\right.$ significant at 0.01 level or better) and CFPS interaction variable $\left(\beta_{7}=-0.009\right.$ significant at 0.01 level) for share price respectively. Foreign ownership also shows significant influence on the value relevance of BVPS as it is reflected by the significant coefficient on the interaction term $\left(\beta_{5}=0.003\right)$ according to the share price.

The sign of the coefficients on the interaction terms is consistent with Hypothesis 1 . Coefficients $\beta_{3}$, $\beta_{5}$ (and $\beta_{7}$ although it is negative) are positive, indicating an increase in the value relevance of the accounting information when foreign ownership is included.

The results show that for companies with foreign ownership, the share price response to EPS is increased, as reflected in the positive coefficient on the earnings interaction term $\left(\beta_{3}\right)$. 
Table 3. Foreign Ownership and Accounting Information Relevance

\begin{tabular}{|c|c|c|c|c|}
\hline \multicolumn{5}{|c|}{$\begin{array}{l}P=\beta_{0}+\beta_{1} \text { FORN }+\beta_{2} \text { EPS }+\beta_{3} \text { EPS FORN }+\beta_{4} \text { BVPS }+\beta_{5} \text { BVPS*FORN }+\beta_{6} \text { CFPS }+\beta_{7} \text { CFPS FORN }+\beta_{8} \text { SIZE }+\beta_{9} \text { LEVRG }+ \\
e_{\text {it }}\end{array}$} \\
\hline Variables & Coef. & Std. Error & t-Statistic & Prob. \\
\hline Constant & $1.328^{*}$ & 0.419 & 3.172 & 0.002 \\
\hline FORN & $-0.207^{* *}$ & 0.096 & -2.165 & 0.031 \\
\hline EPS & $0.040 *$ & 0.003 & 15.547 & 0.000 \\
\hline EPS*FORN & $0.022^{*}$ & 0.005 & 4.685 & 0.000 \\
\hline BVPS & $0.003^{*}$ & 0.001 & 4.646 & 0.000 \\
\hline BVPS*FORN & $0.003 * *$ & 0.001 & 2.339 & 0.020 \\
\hline CFPS & $0.013^{*}$ & 0.001 & 10.953 & 0.000 \\
\hline CFPS*FORN & $-0.009 *$ & 0.002 & -4.391 & 0.000 \\
\hline SIZE & $0.095^{*}$ & 0.021 & 4.528 & 0.000 \\
\hline LEVRG & 0.011 & 0.013 & 0.878 & 0.380 \\
\hline $\mathrm{R}^{2}$ & \multicolumn{4}{|l|}{0.552} \\
\hline Adj. $R^{2}$ & \multicolumn{4}{|l|}{0.549} \\
\hline F-statistics & \multicolumn{4}{|l|}{$172.982^{*}$} \\
\hline P-Value & \multicolumn{4}{|l|}{0.000} \\
\hline
\end{tabular}

Source: Annual Reports (2000-2017)

Notes: i) Date are derived from output on E-Views 10.0

ii) $* * * ; * *$ Significant at $1 \% ; 5 \%$ and $10 \%$ levels respectively

iii) Data have been compiled by researcher.

The reaction of the average annual share price to EPS increased from $0.04\left(\beta_{2}\right)$ to $0.062\left(\beta_{2}+\beta_{3}\right)$, in the presence of foreign ownership. The effect on EPS is in line with previous studies (Bae \& Jeong, 2007 in Korea; Anandarajan \& Hasan, 2010; and Shamki, 2012 in Jordan) that have finished up a noteworthy and positive effect for foreign ownership on the value relevance of earnings. This result could be explained by foreign investment theory, which states that foreign ownership has a material effect on firm value by improving its performance. Hypothetically, it is discovered that higher proportion of foreign ownership has a positive association with the company's performance because it imports advanced information technology and leads to greater economic efficiency (Claessens et al., 2001; Litan et al., 2001; Denizer, 2000; Okuda \& Rungsomboon, 2004; Anandarajan \& Hasan, 2010).

The share price response to BVPS is also increased, as reflected in the positive coefficient on the book value interaction term $\left(\beta_{5}\right)$. The reaction of those share price to BVPS increased from $0.003\left(\beta_{4}\right)$ to $0.006\left(\beta_{4}+\beta_{5}\right)$ in the presence of foreign ownership. The result on EPS is consistent with Shamki, (2012). The results also show that foreign ownership has negative influence on the value relevance of cash flows as it is demonstrated by the coefficients on the interaction term $\left(\beta_{7}\right)$. This result is unexpected, which may explain why cash flow capacity is less than earnings and book value (Wilson, 1986; Dechow, 1994; Barth, 2000; Thi \& Schultze, 2009), and thus, market participants rely more on earnings and book value than on cash flows. Another clarification is that cash flow does not necessarily depend on accounting principles (Hadi, 2005; Velez-Parega, 2005), which can affect its value. Finally, results show that the value relevance of EPS and BVPS relating to the share price is relevant $\left(\beta_{3} \neq 0, \beta_{5} \neq 0\right)$ for companies having foreign ownership in Bangladesh, while this factor has a negative impact on the value relevance of cash flows.

\subsection{Value Relevance and Trading Volume}

Hypothesis (2) states that the value relevance of earnings, book value, and cash flows is greater for companies having larger trading volume. The influence of trading volume has been tested by the Equations 3. Table-4 presents the regression results for the pooled sample with the impact of the company's trade volume relative to the share price. Table 4 shows that the overall $R$-square is 0.559 . The value infers that about $55.9 \%$ of the variation in share price is explained by the independent variables. The result shows that including interaction of trade volume in the regression model adjusted $R^{2}(0.556)$ leads to stronger than 
that of adjusted $R^{2}(0.534)$ in Table 2 . This increase in adjusted $R^{2}$ values is largely attributable to an increase in the effect of trade volume. The significant $F$ statistic indicates that the model as a whole is significant.

The coefficients on EPS $\left(\beta_{2}=0.041\right)$, on BVPS $\left(\beta_{4}=0.003\right)$, and on CFPS $\left(\beta_{6}=0.015\right)$ are significant at 0.01 level and demonstrate the value relevance of EPS, BVPS, and CFPS in the absence of the impact of the trading volume. However, the results show that the coefficients on trading volume $\left(\beta_{1}=0.361\right)$ is significant at 0.01 level. This demonstrates that trading volume is relevant in its right. Trading volume shows significant impact on the value relevance of BVPS and CFPS. This is demonstrated by the significant coefficients on BVPS interaction terms ( $\beta_{5}=0.002$ significant at 0.05 level or better) and CFPS interaction terms $\left(\beta_{7}=-0.006\right.$ significant at 0.01 level or better) for share price respectively. Trading volume has insignificant impact on the value relevance of EPS as it is reflected by the insignificant coefficient on the interaction term $\left(\beta_{3}=0.007\right)$. This result is consistent with the results of Dontoh et al. (2004) and Liu \& Liu (2007) and inconsistent with the result of Shamki (2013).

Table 3. Trade Volume and Accounting Information Relevance

\begin{tabular}{|c|c|c|c|c|}
\hline \multicolumn{5}{|c|}{$\begin{array}{l}P=\beta_{0}+\beta_{1} \text { TRDV }+\beta_{2} \text { EPS }+\beta_{3} \text { EPS } * \text { TRDV }+\beta_{4} \text { BVPS }+\beta_{5} \text { BVPS* TRDV }+\beta_{6} \text { CFPS }+\beta_{7} \text { CFPS } * \text { TRDV }+\beta_{8} \text { SIZE }+\beta_{9} \text { LEVRG }+ \\
e_{\text {it }}\end{array}$} \\
\hline Variables & Coef. & Std. Error & t-Statistic & Prob. \\
\hline Constant & $2.213^{*}$ & 0.428 & 5.174 & 0.000 \\
\hline TRDV & $0.361^{*}$ & 0.058 & 6.225 & 0.000 \\
\hline EPS & $0.041^{*}$ & 0.003 & 11.934 & 0.000 \\
\hline EPS* TRDV & 0.007 & 0.005 & 1.431 & 0.153 \\
\hline BVPS & $0.003^{*}$ & 0.001 & 3.902 & 0.000 \\
\hline BVPS* TRDV & $0.002 * * *$ & 0.001 & 1.901 & 0.058 \\
\hline CFPS & $0.015^{*}$ & 0.002 & 9.260 & 0.000 \\
\hline CFPS* TRDV & $-0.006^{*}$ & 0.002 & -2.756 & 0.006 \\
\hline SIZE & $0.040 * * *$ & 0.022 & 1.844 & 0.065 \\
\hline LEVRG & $0.026 * *$ & 0.013 & 2.020 & 0.044 \\
\hline $\mathrm{R}^{2}$ & \multicolumn{4}{|l|}{0.559} \\
\hline Adj. $R^{2}$ & \multicolumn{4}{|l|}{0.556} \\
\hline \multirow{2}{*}{$\begin{array}{l}F \text {-statistics } \\
P \text {-Value }\end{array}$} & \multicolumn{4}{|l|}{$178.231^{*}$} \\
\hline & \multicolumn{4}{|l|}{0.000} \\
\hline
\end{tabular}

Source: Annual Reports (2000-2017)

Notes: i) Date are derived from output on E-Views 10.0

ii) $* * * ; * *$ Significant at $1 \% ; 5 \%$ and $10 \%$ levels respectively.

iii) Data have been compiled by researcher.

Table 4 shows that for companies with larger trading volume, the share price response to EPS shows no response, as reflected in the insignificant coefficient on the earnings interaction term $\left(\beta_{3}\right)$. The share price response to BVPS is increased, as reflected in the positive coefficient on the book value interaction term $\left(\beta_{5}\right)$. The reaction to BVPS increased from $0.003\left(\beta_{4}\right)$ to $0.005\left(\beta_{4}+\beta_{5}\right)$ in the presence of trading volume. Finally, the results show that the value relevance of BVPS and CFPS relating to the share price is value relevant for companies having larger trading volume, while this factor has no significant impact on the value relevance of earnings.

\section{Conclusions}

This paper explored the impact of economic factors on the value relevance of accounting information for listed manufacturing firms in the Dhaka Stock Exchange, from 2000 to 2017. In this study, foreign ownership and trading volume are used as economic factors. Value-relevance of accounting information is measured by regressing stock price on earnings per share (EPS) and book value per share (BVPS) and cash flow per share (CFPS). Utilizing the fundamental Ohlson (1995) model, this paper finds that EPS, BVPS, and CFPS are value relevant to the share price. The findings showed that foreign ownership has a significant and positive impact on the value relevance of EPS and BVPS but shows a negative impact on CFPS relative to the 
share price. The findings showed that trading volume has a significant and positive on the value relevance of BVPS and CFPS but not on EPS relative to the share price. The paper offers handy commitments to market participants including investors, managers, and financial analysts in addition to its contributions to academia and regulatory bodies. The outcomes may help investors to (1) better understand the company's real financial position by controlling the asymmetric information and (2) improve the control of managers' performance results which is considered in making investment decisions.

Moreover, while many studies focus on examining the value relevance of accounting information, primarily earnings and book value, one significant ramification of the present paper is broadening the valuation model by including cash flows as limited studies investigated the value relevance of this variable together with earnings and book value. This paper likewise inspected the directing impact of the economic factors on the value relevance of the accounting information. Based on the findings of this paper, market participants might be able to conclude the firm value through the company's foreign ownership and trading volume. This paper provides empirical evidence about the indirect influence of the selected economic factors on the market. Accordingly, it will support future regulator work that has a tendency to effectively oversee management to increase the appreciation of the reporting process. This improves the ability of market participants to make the right decisions about market distribution. The findings could be relevant for the courses, such as financial statements analysis and accounting theory and practice. In financial statements analysis courses, the valuation model mainly focused on earnings. Because these variables show significant relationships with share price, the paper provides further evidence of the importance of book value and cash flow, indicating an important relationship between accounting information integrity and information usefulness for market participants.

Future research has to be extended to examine the influence of different economic factors on the value relevance of accounting information which may provide new insights into the possible factors that could influence the value relevance of accounting information. Researchers, who are interested in the area of research, are encouraged to expand the research period and sample size to determine their effects on the accounting information relevance.

\section{References}

1. Admati, A. R., \& Pfleiderer, P. (1988). A theory of intraday patterns: volume and price variability. The Review of Financial Studies, 1(1), 3-40.

2. Al Arussi, A. S., Selamat, M. H., \& Hanefah, M. M. (2009). Determinants of financial and environmental disclosures through the internet by Malaysian companies. Asian Review of Accounting, 17(1), 59-76.

3. Ali, A., and Hwang, L. (2000). Country-specific factors related to financial reporting and the value relevance of accounting data. Journal of Accounting Research, 38(1), 1-25.

4. Alsalman, A. M. (2003). The value relevance of accounting numbers and the implications for international accounting standards harmonization: evidence from Saudi Arabia and Kuwait.

5. Anandarajan, A., \& Hasan, I. (2010). Value relevance of earnings: Evidence from Middle Eastern and North African countries. Advances in Accounting, 26(2), 270-279.

6. Bae, K. H., \& Jeong, S. W. (2007). The value-relevance of earnings and book value, ownership structure, and business group affiliation: Evidence from Korean business groups. Journal of Business Finance \& Accounting, 34(5-6), 740-766.

7. Ball, R., Robin, A., and Wu, J. S. (2003). Incentives versus standards: properties of accounting income in four East Asian countries. Journal of Accounting and Economics, 36 (1-3), 235-270.

8. Bamber, L. S., \& Cheon, Y. S. (1995). Differential price and volume reactions to accounting earnings announcements. Accounting Review, 417-441.

9. Bao, Y. (2004). The value relevance of accounting information: evidence from Asian stock markets (Doctoral dissertation, Kent State University).

10.Barth, M. (1991). Relative measurement errors among alternative pension asset and liability measures. The Accounting Review, 66, 433-463. 
11.Barth, M., and Kallapur, S. (1996). The effects of cross-sectional scale differences on regression results in empirical accounting research. Contemporary Accounting Research, 13, 527-567.

12.Barth, M. E. (2000). Valuation-based accounting research: Implications for financial reporting and opportunities for future research. Accounting \& Finance, 40(1), 7-32.

13.Barth, M. E., Beaver, W. H., \& Landsman, W. R. (1998). Relative valuation roles of equity book value and net income as a function of financial health. Journal of Accounting and Economics, 25(1), 1-34.

14.Barth, M. E., Beaver, W. H., \& Landsman, W. R. (2001). The relevance of the value relevance literature for financial accounting standard setting: another view. Journal of accounting and economics, 31(1-3), 77-104.

15.Beaver, W. H. (1968). The information content of annual earnings announcements. Journal of accounting research, 67-92.

16.Berger, A. N., \& Hannan, T. H. (1998). The efficiency cost of market power in the banking industry: A test of the "quiet life" and related hypotheses. Review of economics and statistics, 80(3), 454-465.

17.Boubakri, N., Cosset, J. C., \& Guedhami, O. (2005). Investor protection, corporate governance and privatization. Journal of Financial Economics, 76, 369-300.

18.Burgstahler, D. C., \& Dichev, I. D. (1997). Earnings, adaptation and equity value. Accounting review, 187-215.

19.Callahan, C., Lee, C., and Yohn, T. (1997). Accounting disclosures and information asymmetry: research opportunities associated with bid-ask spreads. Accounting Horizons, 11(4), 50- 60.

20.Cavana, R., Delahaye, B., \& Sekeran, U. (2001). Applied business research: Qualitative and quantitative methods. John Wiley \& Sons.

21.Caves, R. E. (1971). Industrial corporations: The industrial economics of foreign investment. Economica, 38, 1-27.

22.Chen, C. J., Chen, S., \& Su, X. (2001). Is accounting information value-relevant in the emerging Chinese stock market?. Journal of International Accounting, Auditing and Taxation, 10(1), 1-22.

23.Cheng, C. S., Liu, C., and Schaefer, T. (1997). The value-relevance of SFAS No. 95 cash flows from operation as assessed by security market effects. Accounting Horizons, 11(3), 1-15.

24.Choi, S. B., Lee, S. H., \& Williams, C. (2011). Ownership and firm innovation in a transition economy: Evidence from China. Research Policy, 40(3), 441-452.

25.Claessens, S., \& Demirguc-Kunt, A., Huizinga, H. (2001).“How Does Foreign Entry Affect Domestic Banking Markets?". Journal of Banking and Finance, 25(5).

26.Clark, P. K. (1973). A subordinated stochastic process model with finite variance for speculative prices. Econometrica: journal of the Econometric Society, 135-155.

27.Collins, D. W., Maydew, E. L., \& Weiss, I. S. (1997). Changes in the value-relevance of earnings and book values over the past forty years. Journal of accounting and economics, 24(1), 39-67.

28.Collins, D. W., Pincus, M., \& Xie, H. (1999). Equity valuation and negative earnings: The role of book value of equity. The accounting review, 74(1), 29-61.

29.Cready, W. M. (1988). Information value and investor wealth: The case of earnings announcements. Journal of Accounting Research, 26, 1-27.

30.Cready, W. M., and Mynatt, P. G. (1991). The information content of annual reports: A price and trading response analysis. The Accounting Review, 66, 291-312.

31.Dechow, P. M. (1994). Accounting earnings and cash flows as measures of firm performance: The role of accounting accruals. Journal of accounting and economics, 18(1), 3-42.

32.Denizer, C. (1999). Foreign entry in Turkey's banking sector, 1980-97. The World Bank.

33.Dontoh, A., Radhakrishnan, S., and Ronen, J. (2004). The declining value relevance of accounting information and non-information-based trading: an empirical analysis. Contemporary Accounting Research, 21 (4), 795-812

34.Easton, P., and Harris, T. (1991). Earnings as an explanatory variable for returns. Journal of Accounting Research, 29, 19-36.

35.Easton, P. D. (1999). Security returns and the value relevance of accounting data. Accounting horizons, 13(4), 399-412. 
36.Easton, P. D., \& Sommers, G. A. (2007). Effect of analysts' optimism on estimates of the expected rate of return implied by earnings forecasts. Journal of Accounting Research, 45(5), 983-1015.

37.Easton, P., Harris, T., and Ohlson, J. (1992). Aggregate accounting earnings can explain most of security returns: the case of long event windows. Journal of Accounting and Economics, 15, 119-142.

38.Ely, K., and Waymire, G. (1999). Accounting standard-setting organizations and earnings relevance: longitudinal evidence from NYSE common stocks, 1927-1993. Journal of Accounting Research, 37, 293-318.

39.Epps, T. W., \& Epps, M. L. (1976). The stochastic dependence of security price changes and transaction volumes: implications for the mixture-of-distributions hypothesis. Econometrica: Journal of the Econometric Society, 305-321.

40.Feltham, G. A., \& Ohlson, J. A. (1995). Valuation and clean surplus accounting for operating and financial activities. Contemporary accounting research, 11(2), 689-731.

41.Galai, D., \& Masulis, R. W. (1976). The option pricing model and the risk factor of stock. Journal of Financial Economics (JFE), 3(1/2).

42.Grabowski, H. G., \& Mueller, D. C. (1975). Life-cycle effects on corporate returns on retentions. The Review of Economics and Statistics, 400-409.

43. Hadi, M. (2005). Information content of cash flows data: Evidence for Jordon. Working paper. Kuwait University.

44.Hamada, R. S. (1972). The effect of the firm's capital structure on the systematic risk of common stocks. The journal of finance, $27(2), 435-452$.

45. Harris, M., \& Raviv, A. (1993). Differences of opinion make a horse race. The Review of Financial Studies, 6(3), 473-506.

46.Harris, T. S., Lang, M., \& Mőller, H. P. (1994). The value relevance of German accounting measures: An empirical analysis. Journal of Accounting Research, 32(2), 187-209.

47.Hartmann, F. G., \& Moers, F. (1999). Testing contingency hypotheses in budgetary research: an evaluation of the use of moderated regression analysis. Accounting, Organizations and Society, 24(4), 291315.

48. Hassan, M. S. (2004). The information quality of derivative disclosure in corporate annual reports of Australian firms in the extractive industries (Doctoral dissertation, Queensland University of Technology).

49.Hung, M. (2001). Accounting standards and value relevance of financial statements: an international analysis. Journal of Accounting and Economics, 30(3), 401-420.

50.Jabar, D. S. (2012). The Influence of Institutional Factors on the Value Relevance of Accounting Information: Evidence from Jordan (Doctoral dissertation, University Utara Malaysia).

51.Joos, P., \& Lang, M. (1994). The effects of accounting diversity: Evidence from the European Union. Journal of Accounting research, 32, 141-168.

52.Kandel, E., \& Pearson, N. D. (1995). Differential interpretation of public signals and trade in speculative markets. Journal of Political Economy, 103(4), 831-872.

53.Karma, O., \& Sander, P. (2006). The impact of financial leverage on risk of equity measured by loss-oriented risk measures: An option pricing approach. European journal of operational research, 175(3), $1340-1356$.

54.Karpoff, J. M. (1986). A theory of trading volume. The Journal of Finance, 41(5), 1069-1087.

55.Khanagha, J. B., Mohamad, S., Hassan, T., \& Sori, Z. M. (2011). The impact of reforms on the value relevance of accounting information: Evidence from Iran. African Journal of Business Management, 5(1), 96-107.

56.Kim, O., and Verrecchia, R. E. (1991). Market reactions to anticipated announcements. Journal of Financial Economics, 30, 273-309.

57.Kim, O., \& Verrecchia, R. E. (2001). The relation among disclosure, returns, and trading volume information. The Accounting Review, 76(4), 633-654.

58.Lall, S. (1980). Monopolistic advantages and foreign involvement by US manufacturing industry. Oxford Economic Papers, 32, 102-122.

59.Lev, B. (1974). On the association between operating leverage and risk. Journal of financial and quantitative analysis, 9(4), 627-641. 
60.Li, J. T., and Guisinger, S. (1992). The globalization of service multinationals in the triad nations: Japan, Europe, North America. Journal of International Business Studies, 23(4), 675-696.

61.Litan, E. R., Masson, P., and Pomerleano, M. (2001). Introduction in litan, masson and pomerleano (eds.), open doors: Foreign participation in developing countries. Washington, D.C: Brooking Institute Press.

62.Liu, J., \& Liu, C. (2007). Value relevance of accounting information in different stock market segments: the case of Chinese A-, B-, and H-shares. Journal of International accounting research, 6(2), 5581.

63.Ohlson, J. A. (1995). Earnings, book values, and dividends in equity valuation. Contemporary accounting research, 11(2), 661-687.

64.Okuda, H., \& Rungsomboon, S. (2006). Comparative cost study of foreign and Thai domestic banks in 1990-2002: its policy implications for a desirable banking industry structure. Journal of Asian Economics, $17(4), 714-737$.

65.Ortega, X. (2006). Reinvestigation of value relevance of earnings, book values and cash flow in security prices over time. Journal of finance and Accounting, 2 (9), 34, 47.

66.Ota, K. (2003). The impact of price and return models on value relevance studies: A review of theory and evidence. Accounting Research Journal, 16(1), 6-20.

67.Ou, J., and Penman, S. (1989). Accounting measurement, price-earnings ratios, and the information content of security prices. Journal of Accounting Research, 27, 111-152.

68.Oyerinde, D. T. (2009). Value relevance of accounting information in emerging stock market: The case of Nigeria. In Repositioning African Business and Development for the 21th Century, Proceedings of the 10th Annual Conference.

69.Pallant, J., \& Manual, S. S. (2007). A step by step guide to data analysis using SPSS for windows. SPSS Survival Manual. Open University Press, New York.

70.Penman, S. (1991). An evaluation of accounting rate-of-return. Journal of Accounting, Auditing and Finance, 6 (2), 233-255.

71.Pfleiderer, P. (1984). The volume of trade and the variability of prices: A framework for analysis in noisy rational expectations equilibria. Graduate School of Business, Stanford Univ.

72.Pirie, S., \& Smith, M. (2008). Stock prices and accounting information: evidence from Malaysia. Asian Review of Accounting, 16(2), 109-133.

73.Pugel, T. A. (1981). The determinants of foreign direct investment: An analysis of US manufacturing industries. Managerial and Decision Economics, 2, 220-228.

74.Sethi, D., Guisinger, S. E., Phelan, S. E., and Berg, D. M. (2003). Trends in foreign direct investment flows: A theoretical and empirical analysis. Journal of International Business Studies, 34(4), 315-326.

75.Shamki, D. (2012). Impact of non accounting information on the value relevance of accounting information: The case of Jordan. International Journal of Business and Social Research (IJBSR), 2(1), 9-24.

76.Shamki, D. (2013). The influence of economic factors on the value relevance of accounting information in Jordan. International Journal of Business and Management, 8(6), 89.

77.Shamki, D., \& Abdul Rahman, A. (2012). Value relevance of earnings and book value: Evidence from Jordan. International Journal of Business and Management, 7(3), 133-141.

78.Shamki, D., \& Alulis, I. K. (2016). Company's Characteristics and Accounting Information Relevance. Universal Journal of Accounting and Finance, 4(3), 107-116.

79.Shamki, D., \& Rahman, A. A. (2013). Does financial disclosure influence the value relevance of accounting information?. Education, Business and Society: Contemporary Middle Eastern Issues, 6(3/4), 216-232.

80. Staly, E. (1935). War and the Private Investor: A Study in the Relations of International Politics and International Private Investment. Doubleday, Doran and Company.

81.Suwardi, E. (2009). The dynamic relationship between accounting numbers and share prices on the Jakarta Stock Exchange. International Review of Business Research Papers, 5(5), 16-24.

82.Tauchen, G. E., \& Pitts, M. (1983). The price variability-volume relationship on speculative markets. Econometrica: Journal of the Econometric Society, 485-505.

83.Thi, T. D., \& Schultze, W. (2009). Capitalizing research and development (R\&D): the incremental information content of accruals vs. cash flows for German firms. Working paper, University of Augsburg. 
84.Varian, H. R. (1989). Price discrimination. Handbook of industrial organization, 1, 597-654.

85.Velez-Pareja, I. (2005). Cost of Capital for Non-Traded Firms (Costo de Capital Para Firmas no Transadas en Bolsa)(in Spanish). Academia, Revista Latinoamericana de Administración, (29), 45-75.

86.Verrecchia, R. E. (2001). Essays on disclosure. Journal of accounting and economics, 32(1-3), 97180.

87.Verwijmeren, P., \& Derwall, J. (2010). Employee well-being, firm leverage, and bankruptcy risk. Journal of Banking \& Finance, 34(5), 956-964.

88.Vishnani, S., and Shah, B. (2008). Value relevance of published financial statements- with special emphasis on impact of cash flow reporting. International Research Journal of Finance and Economics, 17, 84-90.

89.Wilson, P. (1986). The relative information content of accruals and cash flows: combined evidence at the earnings announcement and annual report release date. Journal of Accounting Research, 24, 165200. 